\title{
Food Accessibility, Distribution and Production Constraints of Urban Farmers in Ikorodu Metropolis, Lagos State, Nigeria
}

\author{
Edeoghon, C.O. and Izekor, B. \\ Department of Agricultural Economics and Extension Services, Faculty of Agriculture, University of Benin, \\ P.M.B. 1154, Nigeria.
}

\begin{abstract}
This study critically examined food accessibility, distribution and production constraints of urban farmers in Ikorodu Local Government Area of Lagos State, Nigeria. Data was collected using well-structured personally administered questionnaire and interview schedule from 150 urban farmers in the area using multistage sampling technique. Data was analyzed using both descriptive statistics such as frequency counts, percentages, means, standard deviation and rank correlation coefficient was used to test the hypothesis. The urban farmers in this study area had over 8years of basic education, mean family size of 7, farming experience of 12.8years, farm size of 1.94ha, an average proportion (40\%) produce solely for market/sales with monthly income of 22.900 and a large proportion (86.7\%) judge urban farming as profitable. The urban farmers used wholesalers $(\overline{\boldsymbol{x}}=2.22 ; S D=0.17)$, retailers $(\overline{\boldsymbol{x}}=2.34 ; S D=0.31)$, direct sales in market $(\overline{\boldsymbol{x}}=2.30$; $S D=$ $0.19)$, and farm-gate middlemen $(\overline{\boldsymbol{x}}=3.12 ; \mathrm{SD}=1.00)$ in the distribution of farm produce. Furthermore, lack of access to credit, access to inputs, poor storage facilities, lack of skilled labour, limited access to land were major production constraints confronting the urban farmers in the study area. Relationship between socioeconomic characteristics of respondents and their production constraints reveal education to be negatively significant to lack of credit, lack of access to land and lack of extension services. It was recommended that extension services intensify educational programmes and activities among the urban farmers especially as related to storage of agricultural products and market intelligence to know where agricultural goods are needed as well as helping to curb the role of farm gate middlemen.
\end{abstract}

Keywords: food accessibility, production constraints, middlemen, urban farmers, Lagos State.

\section{Introduction}

Pervasive poverty among the urban population in Nigeria is an indication of low agricultural productivity and relatively low incomes. D'Silva and Bysouth (1992) defined absolute poverty as lack of access to resources required for obtaining the minimum necessities essential for the maintenance of physical efficiency. This connotes that the poor farmers will have less access to food, either produced or purchased. Farm families with limited access to productive resources such as land, inputs and capital, required for attaining physical efficiency in food production could be food insecure i.e. resource poverty could lead to low productivity, food insufficiency, and lack of income to purchase the needed calories.

The World Bank (2007) has attested that due to high rate of urbanization, the majority of the poor and the hungry now live in the cities of many developing countries. As of April 2001, the World Bank declared 82 nations as low income food deficit countries (LIFDCs), 42 in Africa, 24 in Asia, 7 in Latin America and the Caribbean, 6 in Oceania and 3 in Europe. These countries are home to the vast majority of the world's 925 million chronically undernourished people. Drescher, (2000) noted that within the next 20 years more poor and undernourished people in developing country will live in cities than in countryside.

Inadequate storage and processing facilities compel urban farmers to sell their surplus during the time of harvest and depend on the market during off-season for their food and for other food products they do not produce. However, urban farmers tend to use distribution means that save time, cost and energy, and enhance easy and quick sale of their produce.

Food distribution systems in urban areas can be categorized by the type of food distributed and by the functions performed. The types of food categories are markets for local staples and other for imported food products. The categories classified by functions are wholesale, retail, farm-gate middlemen and modern distribution outlets, such as supermarkets, self-service groceries and shops (Tollens, 1997).

In developing countries, a large share of food passes through wholesale markets and is then re distributed within the urban area through retail markets, shops, street sellers, and supermarkets, all of which have problems (Argenti, 2000). Storage facilities, particularly cold storage, are insufficient or badly managed or both. These difficulties create additional costs and losses for traders and lead to increased food contamination. At the retail level, supermarkets and hypermarkets (combined supermarkets and department stores) play only a minor role in urban food distribution in developing economies. Even in Latin American cities this sector accounts for only 30 percent of food retail sales, even though it has developed rapidly since the 1970 (Argenti, 
2000), such markets usually cater to the needs of high-income families, are located in middle- to high-income urban areas, and distribute mainly manufactured food products and imports. Staples produced locally are only a small part of these markets' food sales.

The traditional retail food sector dominates developing country markets, making it central to improving food distribution in cities. But public retail markets, which tend to be concentrated in city centers, are usually congested, unhealthy, and insecure. Spontaneous markets are often seen by local city authorities as a cause of traffic, health, and safety problems and the sellers are consequently harassed by municipal police. The study therefore identifies various means of distribution and production constraints of urban farmers.

\section{Methodology}

Lagos State is made up 20 Local Government Areas and 37 Local Council Development Areas. The main urban centers in the State are Badagry, Epe, Ikorodu, Ikeja and Lagos. Ikorodu has a population of 535,071 (NPC, 2007). The land area and population density is $203.00 \mathrm{sq} \mathrm{km}$ and 909 persons per sq km. Ikorodu Local Government Area is the $7^{\text {th }}$ largest LGA among others, is highly urbanized and dominated by agricultural activities than most urbanized areas in Lagos State.

In order to achieve the stated objectives, a multi-stage sampling technique was employed in selecting the samples needed for the study. Purposive selection of Ikorodu Local Government Area of Lagos State was done because it is urbanized and dominated by agricultural activities than most urbanized areas in Lagos. Five (5) communities were randomly selected from Ikorodu LGA while 30 urban farmers were randomly selected from the 5 communities; summing up to 150 respondents.

Primary and secondary data were sourced and hypothesis was tested using the Spearman Rho Correlation Coefficient.

\section{Results And Discussion \\ Socio-economic Characteristics of Respondents}

From the Table, majority $(73.3 \%)$ of the respondents either had at least primary education while $26.7 \%$ had no formal education. The average number of years in school attained was 8.6years. Egbuna (2001) noted that commercial livestock farmers in Abuja, Nigeria spent average of 16 years in school while small ruminant/poultry farmers spent average of 12 years. This observation can be attributed to the technical management practices required for the operations of these enterprises. Unlike crop farmers that spent average of 9 years in school. This was due to conventional method or system of management that require little or no formal education.

The Table also showed that the average family size was 7 persons per household. Aina, Oladapo, Adebosin and Ajijola (2012) obtained similar result for an average household size of 6 persons in their study on livelihood in urban agriculture implication in Ibadan, Nigeria. Large household size is very significant to urban agriculture in terms of labour provision. It was also observed from the Table that about $53.3 \%$ of the respondents own farm land of less than one hectare. The average farm size of the respondents was estimated to be 1.94 hectares. This result agreed with the findings of Edeoghon et al. (2008) who obtained average farm size of 1.78 hectares among arable crop farmers in Edo, Nigeria. This was a common feature of resource-poor urban farmer who practices on-plot cultivation (Foeken and Owuor, 2000). This result implied that urban farmers have limited access to potential agricultural land because of their opportunity cost.

Bourque and Canizares(2000) in his study on policy options for urban agriculture observed that urban agriculture was mainly seen as a temporary use of land until such time when the open space would be incorporated into the city and developed for other uses. This suggests that urban land is more preferred for industrial and residential purposes than agricultural activities.

The study also showed from the Table that the average farming experience was estimated to be 12.80 years. This result corroborated with that estimated by Edeoghon et al. (2008) for arable crop farmers in Edo state, Nigeria when they observed that the average farming experience was 12.01 years. However, Ibadan Multistakeholder team (2007) observed that over 59\% of urban farmers in Ibadan cities have less than 10 years farming experience. This result has a positive correlation with the acquisition of improved skills for agricultural production (Mwangi, 1998). About half (50\%) of the respondents was discovered to have lived in the study area for 6-15 years. Mougeot (2000) observed in his study on urban agriculture, that more often than not urban and peri-urban farmers have already lived in the city for longer periods of time; time that is needed to gain access to urban land, water and other production resources.

The study also revealed from the Table that about $53.3 \%$ of respondents claimed to produce for consumption and sell when there is surplus. A number of studies also pointed out that in poor urban areas food production in home gardens were aimed at producing for self-consumption and generating modest amounts of cash income if possible (Kekana et al., 1999; Nell et al., 2000; Small, 2002; Van Averbeke, 2007). This was the category of farmers that produced for survival as pointed out by Maxwell (1995). This result also agreed with 
the statement made by Moustier and Danso (2006) that in many cities of developing countries, the most frequent type of urban agriculture encountered is the family farm, combining production for self-consumption with sales at the market to raise income. This result tends to show that urban agriculture has the objective of meeting the household food security needs as well as providing income to meet other materials needs.

About half $(53.3 \%)$ of the respondents were part-time farmers. The part-time farmers probably engaged in other non-farming activities to supplement the income from urban agriculture and/or to raise capital for expansion of their farm. Egbuna (2008) stated in her work on urban agriculture in Abuja, Nigeria that part-time urban farmers engaged in other low paid income jobs to complement agriculture. Bakker et.el. (2000) also noted that because of the seasonality of agriculture, some of the farmers engaged in other economic activities such as trading, teaching, hands craft jobs or paid employment. However, Lawal and Aliu (2012) noted that over 77.2\% of vegetable farmers in Lagos, Nigeria were fully engaged in urban vegetable farming as a sole source of livelihood. He noted further that they were farmers who took urban agriculture as a means of livelihood rather than for subsistence.

The Table also showed mode of land acquisition. It observed that majority (62.7\%) did not own the land they were using, this they acquired through rentage (14.7\%), lease $(15.3 \%)$ or outright purchase $(32.7 \%)$. However, about $37.3 \%$ of the respondents claimed to have inherited the land. Adeyemo and Kuhlmann (2009) observed that about $44.2 \%$ of urban producers in Ife and Ibadan acquired the land through rentage, lease, purchase or as a gift. Aina et al. (2012) also supported this view when they stated that about $67.13 \%$ of urban producers in Ibadan metropolis obtained the land through rentage, lease or purchase. It was also observed from the Table that about $25 \%$ of the respondents used mainly family labour. This was a characteristic of poor large family who cannot afford to pay hired labour. Hired labour was mostly used by learned urban farmers who were engaged in other cooperate jobs (Dennery 1995). Hired labour is often employed to manage farm in the absence of the owners.

Large proportion of the respondent $(86.7 \%)$ perceived urban agriculture as a profitable and sustainable engagement while only $13.3 \%$ agreed it was not. From the Table the average monthly income of the respondents was estimated to be $\$ 22,900$. According to the estimation of Mlambo, et.al. (2001), an individual required 286.50 South African Rands i.e. R286.50 (\$33.08 or \$5,200) per month for an active and healthy living in urban area. Therefore, families with average household size of 7 persons will require $\$ 36,400$ a month for sustenance. This is almost one 1.6 times the average monthly income of the respondents. This implied that the respondents were making less income than require to cover their dietary and material needs as urban dwellers. This revealed that the respondents were not completely food secure yet they were not completely food insecure. They probably lie within food insecure without hunger zone because their monthly income went a long way in addressing their food insecurity problem. Similar result was obtained by Yusuf et al. (2008) when they estimated that in Lagos metropolis, average vegetable farmers earned about $\$ 21,760$ a month. It was also estimated from the findings of Egbuna (2001) that average urban vegetable farmers in Abuja city, Nigeria earned as much as $\$ 59,2000$ a month. She further stated that these farmers were the biggest in the cities and had spent up to 15 years in the enterprise, acquiring indispensable investments like boreholes and wells for irrigation and other inputs. This could have helped them to overcome the major constraints facing urban agriculture in other cities of Nigeria. However, a far lesser estimate was obtained by Lawal and Aliu (2012) in their study on contribution of urban agriculture in an emerging megacity Lagos, Nigeria where they obtained average of $\$ 12,500$ per month for the urban farmers.

Table 1: Socio-economic distribution of respondents $(\mathrm{N}=150)$

able 1: Socio-economic distribution of respondents $(\mathrm{N}=150$
\begin{tabular}{|l|l|l|l|}
\hline & Frequency & Percent & Mean \\
\hline Education qualification (years) & & & \\
\hline No formal & 40 & 26.7 & \\
\hline Primary & 20 & 13.3 & \\
\hline Secondary & 65 & 43.3 & 8.60 \\
\hline NCE/OND & 5 & 3.3 & \\
\hline University & 20 & 13.3 & \\
\hline Family size (per household) & & & \\
\hline$<6$ & 70 & 46.7 & \\
\hline $6-10$ & 65 & 43.3 & 7 \\
\hline$>10$ & 15 & 10 & \\
\hline Labour use & & & \\
\hline Family & 37 & 25 & \\
\hline Hired & 53 & 35 & \\
\hline Both & 60 & 40 & \\
\hline Farming experience (years) & & & \\
\hline$<5$ & 22 & 14.7 & \\
\hline $6-10$ & 45 & 30 & \\
\hline $11-15$ & 30 & 20 & 12.80 \\
\hline
\end{tabular}




\section{Source: field survey, 2012}

\begin{tabular}{|l|l|l|l|}
\hline $16-20$ & 23 & 15.3 & \\
\hline$>21$ & 30 & 20 & \\
\hline Average farm size (hectares) & & & \\
\hline$<1$ & 80 & 53.3 & \\
\hline $1-3$ & 25 & 16.7 & 1.94 \\
\hline $4-6$ & 37 & 24.7 & \\
\hline$>6$ & 8 & 5.3 & \\
\hline Years of residence in urban area & & & \\
\hline$<6$ & 43 & 28.7 & \\
\hline $6-10$ & 45 & 30 & 10.59 \\
\hline $11-15$ & 30 & 20 & \\
\hline $16-20$ & 14 & 9.3 & \\
\hline$>21$ & 18 & 12 & \\
\hline Purpose of production & & & \\
\hline Consumption & 10 & 6.7 & \\
\hline Market/sale & 60 & 40 & \\
\hline Both & 80 & 53.3 & \\
\hline Nature of production & & & \\
\hline Fulltime & 70 & 46.7 & \\
\hline Part-time & 80 & 53.3 & \\
\hline Mode of land acquisition & & & \\
\hline Inheritance & 56 & 37.3 & \\
\hline Rentage & 22 & 14.7 & \\
\hline Lease & 23 & 15.3 & \\
\hline Purchase & 49 & 32.7 & \\
\hline Monthly income (N) & & & \\
\hline $6000-10000$ & 20 & 13.3 & \\
\hline $11000-15000$ & 8 & 5.3 & 22,900 \\
\hline $16000-20000$ & 12 & 8 & \\
\hline $21000-25000$ & 25 & 16.7 & \\
\hline$>26000$ & 85 & 56.7 & \\
\hline Job outside agriculture & & & \\
\hline None & 70 & 46.7 & \\
\hline Trading & 35 & 23.3 & \\
\hline Artisans & 15 & 10 & \\
\hline Hand skills & 14 & 9.3 & \\
\hline Public services & 16 & 10.7 & \\
\hline Profitability of UA & & & \\
\hline Profitable & 130 & 86.7 & \\
\hline Non profitable & 20 & 13.3 & \\
\hline & & & \\
\hline
\end{tabular}

\section{Distribution of Food by Urban Farmers and Indicators of Food Accessibility}

The Table 2 shows regular use of farm-gate middlemen $(\mathrm{M}=3.12)$ in the distribution of food by the urban farmers. Anthonio (1970) in his work on distributors in foodstuffs in Nigeria, emphasized the importance of farm-gate middlemen in food distribution in Nigeria. He said the farmers were very close to the farm-gate middlemen and this enhanced the 'buy-and-sell' relationship between them. This was the major factor that accounted for their prevalence in food distribution sector especially in the peri-urban areas. A research work carried out by Olayemi in 1974 on food marketing and distribution problems revealed that a major constraint of farm-gate middlemen was buying too cheap from the farmers at the farm gate which did not reflect the effort of the farmers. He explained further that the farm-gate middlemen took advantage of urgent need of cash income on the part of the farmers to exploit them.

The result also showed regular use of wholesalers $(M=2.22)$ and retailers $(M=2.34)$ in the food distribution of food by the farmers. The wholesalers, as observed by Jones (1972) in his study on marketing of stable food crops in tropical Africa, buy majorly from large scale farmers or from three to four small scale farmers and then assemble the produce which they transport to other parts of the country or export. Retailers, on the other hand, buy from small-scale urban farmers or from wholesalers. Anthonio (1970) pointed out the significance of retailers in ensuring efficient food distribution within the immediate community of the farmers. Argenti (2000) pointed out that low income urban farmers tend to sell their food to local fruit, vegetable and meat retailers or neighborhood kiosks that buy staples. These retail markets were frequently small and scattered.

The study also showed that direct sale $(M=2.30)$ of produce in the market by farmers themselves was also significant. This is very significant as some of the farmers were able to trade their produce for other varieties of food they were not producing. De Zeeuw, Van Veenhuizen and Dubbeling (2011) in their work on role of urban agriculture in building resilient cities, observed that much of the food produced by urban farmers is bartered or sold locally by the farmers themselves. 
The study (from the Table) also showed irregular use of commissioned agents $(\mathrm{M}=1.11)$ and noncommissioned agents $(M=1.71)$ in food distribution by the farmers. This was basically because of the technicality and complexity involved in their operations. There was no significant use of supermarket in the distribution of food by urban farmers. This justified the conclusion of Garnett (2000) that most supermarkets were placed in central locations, out of the periphery of the urban farmers. This finding also confirmed the statement of Yeudall (2006) in her work on nutritional perspectives on urban agriculture that locally produced food distributed by regular channels was fresher, more nutritious and diverse than food products bought in supermarkets or in fast food chains; it also leads to more regular food intake among the farmers.

The dispersions from means for wholesaler (2.22 \pm 0.17$)$, retailers $(2.34 \pm 0.31)$, farm-gate agents (3.12 \pm 1.0$)$ and direct sale by farmers $(2.30 \pm 0.19)$ are very small and therefore; do not affect the significance of the means. The Table also showed some indicators of food accessibility by urban farmers. Inability of farmers to purchase food quickly from market $(M=1.51)$ showed that food was not readily available within the reach of the farmers even when they have purchasing power. Buying at extremely too high price $(M=2.45)$ especially during the off-season compelled the farmers to go for less wholesome food at lower cost. This indicated that though the farmer was food secure during on-season, that status could not be maintained throughout the year. Also inability to buy desired food $(M=2.37)$ because it was completely out of the market showed the farmers cannot stored their food for a time sufficient enough to ensure food security all the year round. Also inability to sell produce on time $(M=2.18)$ was found to be the major cause of cash shortage for the farmers. This generally resulted in spoilage due to high perishability of the produce (Inyanga, 2008). However, buying from neighbor farmers (M= 2.41 ) enhanced food accessibility by the urban farmers. This also enabled them to have access to varieties of wholesome food as when needed.

The dispersions around means for buying food at high prices $(2.45 \pm 0.39)$ and inability to buy desired food $(2.37 \pm 0.27)$ are very small and hence, do not affect the significance of the means. This showed that food inaccessibility was strongly correlated with high prices of food and inability to buy desired food. However, the result also showed that dispersion from mean for buying from neighbor farmers $(2.41 \pm 0.3)$ are very small and therefore do not affect the significance of the mean. This finding implied that urban farmers attained higher level of food accessibility by buying from fellow farmers in the neighborhood who sell food not produced by the farmers. This is a significant feature of community garden as observed in Havana, Cuba (Cuba Ministry of Agriculture, 2008). Inability to sell produce was a strong negative indicator of food accessibility as this could just be because of lack of market intelligence of the forces of demand and supply. This can also lead to great losses as farmers are forced to sell at giveaway prices because of the perishability nature of agricultural products as well as the problem of poor storage and processing facilities inherent among the urban farmers $(\overline{\boldsymbol{x}}=2.29 ; \mathrm{SD}$ $=0.0 .2$ : Table 3 ).

Table 2 food distribution agents and indicators of food accessibility

\begin{tabular}{|c|c|c|c|c|c|c|c|c|}
\hline \multirow[b]{2}{*}{ Distribution agents } & \multicolumn{2}{|c|}{ Always } & \multicolumn{2}{|c|}{ Sometimes } & \multicolumn{2}{|c|}{ Never } & \multicolumn{2}{|c|}{ Total } \\
\hline & Freq & $\%$ & Freq & $\%$ & Feq & $\%$ & Mean & SD \\
\hline Wholesalers & 53 & 35.5 & 43 & 28.7 & 54 & 36 & $2.22 *$ & 0.17 \\
\hline Retailers & 71 & 47.3 & 77 & 46.7 & 2 & 1.3 & $2.34 *$ & 0.31 \\
\hline Commissioned agents & 10 & 6.7 & 48 & 31.3 & 92 & 61.3 & 1.11 & 2.22 \\
\hline Non-commissioned agents & 31 & 20.7 & 44 & 29.3 & 75 & 50 & 1.71 & 1.28 \\
\hline Direct sale in markets & 82 & 54.7 & 38 & 25.3 & 30 & 20 & $2.30 *$ & 0.19 \\
\hline Farm-gate middlemen & 75 & 50 & 35 & 23.3 & 40 & 26.7 & $3.12 *$ & 1.00 \\
\hline Indicators & \multicolumn{2}{|c|}{ Yes } & \multicolumn{2}{|c|}{ No } & \multicolumn{2}{|c|}{ Can't tell } & \multicolumn{2}{|c|}{ Total } \\
\hline & Freq & $\%$ & Freq & $\%$ & Feq & $\%$ & Mean & SD \\
\hline Quick purchase of food & 25 & 16.7 & 39 & 26 & 89 & 59.3 & 1.51 & 1.22 \\
\hline Buy food at high prices & 70 & 46.7 & 43 & 28.7 & 37 & 24.7 & $2.45^{*}$ & 0.39 \\
\hline Unable to buy desired food & 81 & 54 & 37 & 24.7 & 32 & 21.3 & $2.37 *$ & 0.27 \\
\hline purchase from neighbor farm & 79 & 52.7 & 53 & 35.3 & 18 & 12 & $2.41 *$ & 0.30 \\
\hline Distant market & 47 & 31.3 & 53 & 35.3 & 50 & 33.3 & 1.98 & 1.21 \\
\hline Unable to sell produce & 66 & 44 & 45 & 30 & 39 & 26 & $2.18^{*}$ & 0.19 \\
\hline
\end{tabular}

Source: field survey, 2012

$*$ Regular $($ mean $>=2.00)$

\section{Production Constraints Faced by Urban Farmers}

Urban farmers can only attain food security through efficient production of food in the cities. As shown on Table 3, inadequate/lack of extension services $(M=2.38)$ ), lack of skilled labour $(M=2.16)$, poor storage facility $(M=2.09)$, high cost of inputs $(M=2.22)$ and lack of access to land $(M=2.10)$ were the major significant constraints faced by urban farmers in the study area in their bid to ensure their families were food secure. The dispersions around means for lack of extension services (2.38 \pm 0.3$)$, lack of skilled labour (2.16 \pm 0.1$)$, distant market (2.34 \pm 0.2$)$, poor storage facility (2.29 \pm 0.12$)$, high cost of inputs $(2.23 \pm 0.20)$, and lack of access to land $(2.20 \pm 0.17)$ are very small and therefore do not affect the significance of the means; indicating very serious challenges. 
Adekunle et al., as cited in Akpan (2010) identified that urban farmers have limited security tenure because of opportunity cost of land especially for residential and commercial purposes. This is a primary constraint as land is the major resource on which agricultural activities lie. Urban farmers with better access to production resources and credit facility tend to be economically better-off and more food secure than those without. Inability to preserve farm produce during the time of harvest has denied urban farmers from enjoying quality and wholesome food throughout the year. Kutiwa et al., (2010) discovered that $62 \%$ of urban farmers in Harare, Zimbabwe can only store up farm produce for only a period of 1 to 3 months then suffered food insufficiency for the rest of the months. Other production constraints observed in the study area were poor distribution method $(M=2.03)$, low purchasing power $(M=2.08)$, poor electricity supply $(M=2.10)$, pests and diseases (2.21) distant market $(\mathrm{M}=2.02)$ and inadequate information $(\mathrm{M}=2.03)$. The dispersions from means for these constraints are very large hence they affect the significance of the means; indicating less serious constraints or challenges.

Table 3 Production constraints faced by urban farmers

\begin{tabular}{|c|c|c|c|c|c|c|c|c|}
\hline \multirow[t]{2}{*}{ Constraints } & \multicolumn{2}{|c|}{ Serious } & \multicolumn{2}{|c|}{ Not serious } & \multicolumn{2}{|c|}{ Not very serious } & \multicolumn{2}{|c|}{ Total } \\
\hline & Freq & $\%$ & Freq & $\%$ & Freq & $\%$ & Mean & SD \\
\hline High cost of inputs & 63 & 42 & 57 & 38 & 30 & 20 & $2.23 *$ & 0.2 \\
\hline Inadequate/ lack of extension services & 43 & 28.7 & 61 & 40.7 & 46 & 30.7 & $2.38 *$ & 0.3 \\
\hline Inadequate /lack of credit facility & 59 & 39.3 & 65 & 43.3 & 26 & 17.3 & $2.22 *$ & 0.6 \\
\hline Lack of access to land & 69 & 46 & 27 & 18 & 54 & 36 & $2.10 *$ & 0.1 \\
\hline Poor storage and processing facility & 57 & 38 & 50 & 33.3 & 43 & 28.7 & $2.29 *$ & 0.2 \\
\hline Poor distribution of output & 25 & 16.7 & 59 & 39.3 & 66 & 44 & $2.73 *$ & 1.0 \\
\hline Inadequate and inconsistent government policies & 38 & 25.3 & 70 & 46.7 & 42 & 28 & 1.97 & 0.7 \\
\hline Low purchasing power & 62 & 41.3 & 38 & 25.3 & 50 & 33.3 & $2.08 *$ & 0.9 \\
\hline Poor electricity supply & 70 & 46.7 & 25 & 16.7 & 55 & 36.7 & $2.10 *$ & 0.4 \\
\hline Pests and diseases & 66 & 44 & 50 & 33.3 & 34 & 22.7 & $2.21 *$ & 0.8 \\
\hline Theft and insecurity & 25 & 16.7 & 80 & 53.3 & 45 & 30 & 1.87 & 0.7 \\
\hline Inadequate information & 45 & 30 & 65 & 43.3 & 40 & 26.7 & $2.03 *$ & 0.7 \\
\hline Poor planting materials & 43 & 28.7 & 58 & 38.7 & 49 & 32.7 & 1.96 & 0.6 \\
\hline Poor road network & 44 & 29.3 & 39 & 26 & 67 & 44.7 & 1.85 & 0.8 \\
\hline Lack of skilled labour & 57 & 38 & 60 & 40 & 33 & 22 & $2.16^{*}$ & 0.1 \\
\hline Distant market & 38 & 25.3 & 62 & 41.3 & 50 & 33.3 & $2.02 *$ & 0.7 \\
\hline Illness/ sickness & 23 & 15.3 & 45 & 30 & 82 & 54.7 & 1.61 & 0.5 \\
\hline
\end{tabular}

Relationship between Socio-Economic Characteristics of Respondents and their Production Constraints

Table 4 shows the relationship between socio-economic characteristics of respondents and their production constraints. It was obvious from the Table that there was no significant correlation between any of the socio-economic characteristics of respondents and high cost of inputs. This could be attributed to the fact that the prices of inputs are determined by uncontrollable forces of demand and supply. There was no correlation between lack of extension services and socio-economic characteristics except for education status that had negative and significant correlation with lack of extension services $(r=-0.94, p=0.040)$. Education is also negatively significant among the socioeconomic characteristics as related to lack of credit and lack of access to land. This negative correlation implies that higher education of farmers will improve their access to credit, extension services and land.

Poor storage also has a negative correlation with socioeconomic characteristics of farmers indicating that poor storage was mainly caused by low educational level of farmers while the negative correlation of farm size indicated that larger farm sizes will attract more access to credit as well as land. This could be because larger farm sizes will naturally give the urban farmer a "voice" and influence that could attract other productive resources.

Table 4 Relationship between socio-economic characteristics of respondents and their production constraints (N $=150$ )

\begin{tabular}{|l|l|l|l|l|l|l|l|l|}
\hline \multirow{2}{*}{ Constraints } & \multicolumn{2}{l|}{ EDUCATION } & \multicolumn{2}{l|}{ FAMILY SIZE } & \multicolumn{2}{l|}{ LABOUR USE } & \multicolumn{2}{l|}{ FARM SIZE } \\
\cline { 2 - 9 } & r & Prob & r & Prob & r & Prob & r & prob \\
\hline High cost of inputs & 0.141 & 0.64 & 0.003 & 0.98 & 0.215 & 0.53 & 0.331 & 0.42 \\
\hline Lack of extension services & $-0.94^{*}$ & 0.041 & 0.420 & 0.12 & 0.089 & 0.06 & 0.013 & 0.55 \\
\hline Lack of credit & $-0.63^{*}$ & 0.03 & 0.530 & 0.13 & 0.020 & 0.25 & -0.25 & 0.66 \\
\hline Lack of access to land & $-0.530^{*}$ & 0.043 & 0.000 & 0.05 & 0.00 & 0.14 & -0.25 & 0.021 \\
\hline Poor storage & -0.28 & 0.08 & 0.480 & 0.75 & 0.003 & 0.03 & 0.060 & 0.30 \\
\hline Low purchasing power & 0.130 & 0.03 & 0.130 & 0.13 & 0.014 & 0.25 & 0.420 & 0.12 \\
\hline Poor electricity supply & 0.221 & 0.71 & 0.000 & 0.05 & 0.244 & 0.73 & 0.148 & 0.71 \\
\hline Poor road & 0.012 & 0.67 & 0.004 & 0.88 & 0.012 & 0.95 & 0.101 & 0.45 \\
\hline
\end{tabular}

Source: field survey, $2012 \quad$ *significant at 5\% level (0.050) 
Summary

\section{Summary, Conclusion And Recommendation}

The urban farmers in this study area used wholesalers, retailers and farm-gate middlemen in the distribution of farm produce. Furthermore, lack of access to credit, access to inputs, limited access to land, poor storage facilities, lack of skilled labour were major production constraints confronting the urban farmers in the study area. Relationship between socio-economic characteristics of respondents and their production constraints reveal education to be negatively significant to lack of credit, lack of access to land and lack of extension services.

\section{Conclusion}

With intensified education on market intelligence and storage, urban farmers can have a better part of the profit distribution in the marketing chain.

\section{Recommendations}

1) Extension services intensify educational programmes and activities among the urban farmers especially as related to storage and processing of agricultural products.

2) Extension education on market intelligence should expounded to urban farmers to know where agricultural goods are needed as well as helping to curb the role of farm gate middlemen who take a large proportion of the profit that would have been the urban farmers'

\section{References}

[1]. Adedosin and Ajijola, (2012). Urban Livelihood: Urban Agriculture Implication in. Food Security, A Case Study of Ibadan Metropolis. Journal of Applied Phytotechnology in Environmental Sanitation.

[2]. Adeyemo, R. and Kuhlmann, F. (2009). 'Resource Use Efficiency in Urban Agriculture in Southwestern Nigeria', Tropicultura. 27(1): 49-53. Agriculture in Abakaliki Area, Nigeria', Ph.D dissertation. Stanford University.

[3]. Aina, O.S; Oladaopo, A. Adebosun, W.G; and Ajijola, S. (2012). Urban Livelihood: Urban Agriculture Implication in Food Security, A Case Study of Ibadan Metropolis. Journal of Applied Hydro-Technology in Environmental Sanitation. Jakarta. Vol 1. (4). Pp. $155-161$.

[4]. Akpan, Sunday Brownson. (2010). "Encouraging Youth's Involvement in Agricultural Production and Processing; NIGERIA STRATEGY SUPPORT PROGRAM (Policy Note No. 29) ", edited by International Food Policy Research Institute. Abuja, Nigeria: CGIAR.

[5]. Anthonio, G.B.O., (1970). Fish marketing survey in the Kainji Lake Basin Yelwa area study. Ibadan, Nigerian Institute of Social and Economic Research, May.

[6]. Argenti, O. (2000). 'Food for the Cities: Food Supply and Distribution Policies to Reduce Urban Food Security', Food and Agriculture Organization (FAO) / Programa de Gestion Urbana. Food into Cities ; DT/43-OOE / Cuaderno de Trabajo, no. 77.

[7]. Bakker, N, M Dubbeling, S Gundel, U Sabel-Koschela and H de Zeeuw (editors) ( 2000), Growing Cities, Growing Food: Urban Agriculture on the Policy Agenda. A Reader on Urban Agriculture, Deutsche Stiftung fur internationale Entwicklung (DSE), Germany.

[8]. Bourque and Cañizares, K. (2000). 'Urban Agriculture in Havana, Cuba.

[9]. Cuba Ministry of Agriculture (2008). Cuba's Organic Revolution. The Guardian. $4^{\text {th }}$ April, 2008.

[10]. Dennery, P. (1995). 'Cities Feeding People Project fact sheets'. Cities Feeding

[11]. De zeeuw, H., Van Veenhuizen, R., and M. Dubbeling, (2011)"The role of Urban Agriculture in building resilient cities in developing countries". Journal of Agricultural Science. United Kingdom: Cambridge University Press

[12]. Drescher, (2000). 'Urban Food Security: Urban Agriculture, a Response to Crisis?' Urban Agriculture Magazine (2000) 1.1.

[13]. D'Silva, E. and Bysouth, K. (1992). Poverty Alleviation through Agricultural Projects: Report on a Seminar held jointly by the Asian Development Bank and the Economic Development Institute of the World Bank. Washinton D.C.

[14]. Edeoghon, C.O; Ajayi, M.T. and Ugboya, T.O. (2008). Awareness and Use of Sustainable Agricultural Practices by Arable Farmers in Ikpoba-Okha Local Government Area of Edo State. Journal of Sustainable Development in Agriculture and Environment. 3 (2). Pp $55-63$.

[15]. Egbuna, E.N. (2008). Urban Agriculture: A Strategy for Poverty Reduction in Nigeria.CBN, Abuja, Nigeria.

[16]. Egbuna, E.N. (2001). 'Urban Agriculture and Food Security in Abuja: An enquiry', Nigeria.

[17]. Foeken, Dick and Owuor, S.O. (2000). Livestock in a middle-sized East-African town: Nakuru. Urban Agriculture Magazine. no. 2. Livestock in and around cities, Leusden, RUAF.

[18]. Garnett, T. (2000). Urban Agriculture in London: Rethinking our Food Economy. City Case Study London. Pp 24.

[19]. Ibadan Multi-Stakeholder Team, (2007). City Farming for the Future, Ibadan, Nigeria. A Strategic Agenda for the Development of Urban and Peri-urban Agriculture. RUAF Foundation.

[20]. Inyanga, J. (2008), Group influence on consumer behavior. Journal of business and Social Sciences. 3(1), 69-83.

[21]. Jones, W.O. (1972). Marketing Staple Foods in Tropical Africa. Ithaca NY, Cornell University Press.

[22]. Kekana, D.S., Van Rooyen, J., and Van Den Heever, E. (1999). 'Discovering Urban Agriculture: The Soshanguve Study',Farmer's Weekly (1), April 30:28-30.

[23]. Kuhlmann, F. (2009). 'Resource Use Efficiency in Urban Agriculture in Southwestern Nigeria', Tropicultura. 27(1): 49-53. Agriculture in Abakaliki Area, Nigeria', Ph.D dissertation. Stanford Univ.

[24]. Kutiwa, S; Emmanuel, B and Dimitri, D. (2010). Urban Agriculture in Low Income Households of Harare: An Adaptive Response to Economic Crisis. Human Ecology Department, Vrije Universiteit Brussel, Belgium. Ecol, 32(2): 85-96

[25]. Lawal, M.O. and Aliu, I.R., 2012: Operational pattern and contribution of urban farming in an emerging megacity: evidence from Lagos, Nigeria. In: Szymańska, D. and Biegańska, J. editors, Bulletin of Geography. Socio-economic Series, No. 17, Toruń: Nicolaus Copernicus University Press, pp. 87-97. DOI: 10.2478/v10089-012-0009-1

[26]. Maxwell, D. (1995). 'Alternative Food Security Strategy: A Household Analysis of Urban Agriculture in Kampala.' World Development. Vol. 23(10), 1669-1681. 
[27]. Mlambo, V. ; Mould, F. ; Mueller-Harvey, I. ; Owen, E. ; Ndlovu, L. ; Mugabe, P. ; Sikosana, J. ; Smith, T., (2001). Chemical composition and in vitro fermentation characteristics of Acacia and other tree pods (R7351). In: Sustaining livestock in challenging dry season environments. Strategies for smallscale livestock farmers (T. Smith, S. H. Godfrey, eds.). Proc. 3rd Workshop on Livestock Production Programme Projects, Ingwe Lodge and ICRISAT, Matopos, Zimbabwe.

[28]. Mougeot, L. J. A. (2000). 'Urban Agriculture: Definition, Presence, Potentials and Risks. In Growing Cities, Growing Food' Urban Agriculture on the Policy Agenda. A Reader on Urban Agriculture. Germany: Feldafing. 99-117.

[29]. Moustier P., Danso G. (2006) Local economic development and marketing of urban produced food, in: van Veenhuisen René (Ed.), Cities farming for the future: Urban agriculture for green and productive cities, RUAF Foundation, International Institute of Rural Reconstruction, International Development Research Centre, PO Box 8500, Ottawa, ON K1G 3H9, Canada, pp. 173-208.

[30]. Mwangi A. M. (1998). The role of urban agriculture for food security in low-income areas in Nirobi. Leiden: African Studies Center.

[31]. Nell, W., Wessels, B., Mokoka, J., and Machedi, S., (2000). 'A Creative Multidisciplinary Approach Towards the Development of Food Gardening'. Development Southern Africa, 17(5):807-819.

[32]. NPC, (2007). Advertorial- National Population Commission: Lagos State.

[33]. Olayemi, J.K. (1974). Cost and Returns to Cocoa and Alternative Crops in Western Nigeria. In: Kotey, Okali and Rourke, eds; 1974. Pp. $48-58$.

[34]. Small, R. (2002). 'Lessons from the Cape Flats Townships: Ecological Micro-Farming among the Poor in Cape Town'. Urban Agriculture Magazine. April: 30-31.

[35]. Tollens, E.F. (1997). Market Information Systems in sub-Sahara Africa Challenges and Opportunities. Poster paper prepared for presentation at the International Association of

[36]. Agricultural Economists Conference, Gold Coast, Australia. August 12-18.

[37]. Van Averbeke, W. (2007). 'Urban Farming in the Informal Settlements of Atteridgeville, Pretoria, South Africa'. Water Sa, 33(3):337-342.

[38]. World Bank, (2007). 'Haiti: Social Resilience and State Fragility in Haiti', A Country Social Analysis, Report no 36069-HT, the World Bank, Washington DC.

[39]. Yeudall, F. (2006). 'Nutritional Perspectives in Urban And Peri Urban Agriculture'. In Health Risks And Benefits of Urban and Peri-Urban Agriculture and Livestock in Sub-Saharan Africa, Urban Poverty and Environment Series Report 1. Ottawa, Canada: Idrc, 25-34.

[40]. Yusuf, L; Oladunmoye, M.K.; Ogundare, A.O; Akinyosoye, F.A; Daudu, O.A.Y and Hassan, G.A (2008). Antimicrobial and Antioxidant Properties of Mistletoe (viscum album) Growing on Cola (cola nitida) Tree in Akure North, Nigeria. Journal of Microbiology Research and Reviews. Vol. 1 (3): 35 - 41, August, 2013. 7pp. 